\title{
Adiponectin as a Biomarker of the Metabolic Syndrome in CHILDREN AND Adolescents
}

\author{
B. Pyrzak ${ }^{1}$, M. Ruminska 1 , K. Popko 2 , U. Demkow ${ }^{2}$ \\ ${ }^{1}$ Department of Pediatrics and Endocrinology, Warsaw Medical University, Warsaw, Poland; \\ ${ }^{2}$ Department of Laboratory Diagnostics and Clinical Immunology of the Developmental Age, Warsaw Medical University, Warsaw, Poland
}

\begin{abstract}
The prevalence of obesity in children and adolescents has been increasing worldwide. As in adults, childhood obesity is closely related to hypertension, dyslipidemia, type 2 diabetes, and insulin resistance (IR) syndrome. Moreover, obese children have been found to be at increased risk of becoming obese adults. Obese children and adolescents tend to develop serious medical and psychosocial complications and also are at greater risk morbidity and mortality in adulthood. The molecular basis of the pathogenesis of obesity-linked disorders has not been fully elucidated. Adipose tissue serves not only as an energy storage organ, but also as an endocrine organ. It releases many factors with autocrine, paracrine and endocrine functions. Adipokines such as leptin, resistin, tumor necrosis factor- $\alpha$, interleukin-6, adipsin, visfatin, and adiponectin are biologically active molecules produced by adipose tissue. They play a role in energy homeostasis, and in glucose and lipid metabolism. Adiponectin level, unlike that of other adipocytokines, is decreased in obesity and increased after weight reduction. Adiponectin has been associated with both central obesity and increased visceral adipose tissue and it has anti-inflammatory, anti-atherogenic, and potent insulin-sensitizing (anti-diabetic) effects.
\end{abstract}

Key words: Adiponectin, metabolic syndrome, children

\section{Adiponectin Structure}

Adiponectin is an adipocyte-derived hormone discovered in 1995. Adiponectin is dramatically up-regulated during adipogenesis and remains one of the most adipocyte-specific gene products identified to-date [1, 2]. It is also known as ACRP30, apMI, adipoQ, and GBP28. The initial identification of this protein was made by isolation of a cDNA using a subtractive hybridization screen designed to identify genes up-regulated during adipocyte differentiation [3]. Adiponectin consists of an amino-terminal signal sequence, a variable region and a collagenous domain. Adiponectin protein, in its most basic form, is a homotrimer of three $30 \mathrm{kDa}$ subunits. The trimers associate trough disulphide bindings within the collagenous domains of each monomer to form bouquet-like structures. These higher order structures include low-molecular weight (LMW) hexamers of $180 \mathrm{kDa}$ and high-molecular weigh (HMW) 16-18mers of $>400 \mathrm{kDa}$. Together, these complexes make up approximately $0.01 \%$ of total serum protein (circulating at approximately $10 \mu \mathrm{g}$ $\mathrm{ml}^{-1}$ ). Adipocytes secrete both the LMW and HMW forms of adiponectin which predominate in serum, while smaller complexes, such as trimers are undetectable. Neither LMW nor HMW interchange with each other after secretion into the serum or culture medium [4]. These findings suggest that circulating pools of LMW and HMW complexes may constitute precursors for processing into the form of trimers at the target cell surface.

\section{ANIMAl StUdies}

To characterize adiponectin action in target tissues, a number of studies have been performed to test the effects of exogenous adiponectin in animal models. Several authors have described the effects of recombinant, full-length adiponectin, or a proteolytic cleavage product (the globular 'head' domain of adiponectin) on the circulating levels of glucose, and free fatty acids and triglycerides, accompanied by weight loss in mice [5]. Recombinant adiponectin reduces serum glucose level in normal and diabetic rodents without stimulation of insulin secretion [6].

Adiponectin also markedly enhances the ability of insulin to suppress glucose production by isolated hepatocytes. A recent study has shown that phosphorylation and activation of the 5'-AMP-activated protein kinase were stimulated in the liver with globular and fulllength adiponectin [7]. This observation leads to the hypothesis that glucose-lowering effect of adiponectin in vivo could be mediated via a direct muscle and hepatic action. However, data obtained in experiments involving the injection of fragments of recombinant adiponectin into rodents may not reflect the normal action of the native protein. It has recently been shown that endogenous adiponectin secreted by adipocytes is post-translationally modified into eight different isoforms. Six of the adiponectin isoforms are glycosylated at four lysine residues located in the collagenous domain of adiponectin [8].

Functional analysis has revealed that full-length adiponectin produced by mammalian cells is more potent than the recombinant form in enhancing insulin sensitivity, whereas this ability is attenuated when glycosylated lysines are substituted with arginine [8]. In 
the light of these observations, the relevance of the reported pharmacological effects to the physiological role of adiponectin is unclear. Recently, mice lacking adiponectin have been generated by gene targeting, and experimental studies have clarified some aspects of adiponectin physiology. Kubota et al [9] have reported that heterozygous adiponectin-deficient (Adipo $-/+$ ) mice show mild insulin resistance, while homozygous adiponectin-deficient (Adipo -/-) mice show moderate insulin resistance with glucose intolerance, despite body weight gain similar to that of wild-type mice. In another study Maeda et al [10] have reported that adiponectin knock-out mice show a delayed clearance of free fatty acid from plasma and low levels of fatty acid transport protein-1 mRNA into muscles. There is no evidence of insulin resistance when adiponectin knock-out mice are fed with regular food. However, these authors have found that feeding the Adipo -/- mice a high-sucrose diet for 2 weeks induces insulin resistance in these animals. In contrast, experiments reported by $\mathrm{Ma}$ et al [11] have shown that plasma glucose and insulin levels, and the results of i.p. glucose and insulin-tolerance tests all are similar in both Adipo -/- and Adipo +/+ mice. The simultaneous hyperinsulinemic-euglycemic analysis also shows similar glucose infusion rates required to maintain similar glucose levels in both groups of mice. These findings suggest that adiponectin deficiency is implicated in the induction of insulin resistance in some circumstances and this protein may play a protective role against insulin resistance. On the other hand, it has been reported that insulin resistance in cachectic mice has been reversed by a combination of physiological doses of adiponectin and leptin, but only partially by either adiponectin or leptin alone [12]. These data suggest that replenishment of adiponectin might provide a novel treatment modality for insulin resistance and type 2 diabetes. Moreover, reduction of adiponectin level seems to be implicated in the development of insulin resistance in murine models of both obesity and lipoatrophy. Several authors have shown that the expression of adiponectin gene is strongly suppressed by $\beta$-adrenergic stimulation $[13,14]$.

\section{Studies in Adult Humans}

As adiponectin is produced by the adipocyte tissue, it is not surprising that its concentrations in the serum are related to adipose tissue mass. Unlike most adipose-derived hormones and secreted proteins, adiponectin mRNA and serum levels are decreased in obesity $[15,16]$. A study, involving 967 Japanese normal weight subjects, has shown that plasma adiponectin negatively correlates with body mass index, systolic and diastolic blood pressure, fasting plasma glucose, insulin, insulin resistance (HOMA-IR), total and lowdensity lipoprotein-cholesterol, triglycerides and uric acid, and positively with high-density lipoprotein HDL-cholesterol [17]. These correlations were significant even after adjustment for age, sex, and BMI. Similarly to plasma leptin level, adiponectin concentration seems to be gender-dependent (higher among women than men) $[17,18]$. Furthermore, a limited number of studies have so far reported that plasma adiponectin level is reduced not only among obese patients [16], but also among patients with some of the disease frequently associated with obesity, such as type 2 diabetes mellitus [18] and coronary heart disease [19].

A study by Hotta et al [19] has shown that adiponectin level is lower in patients with type 2 diabetes than in non-diabetic patients, and is particularly low in subjects with coronary artery disease. The presence of microangiopathy does not affect the plasma adiponectin level in diabetic patients. In that study, plasma adiponectin concentration negatively correlated with plasma glucose, insulin and triglyceride level, and with body mass index, but positively with of HDL level. In a recent study performed on 23 Caucasians and 121 Pima Indians [20], plasma adiponectin concentrations negatively correlated with the percentage of body fat, waist-to-hip ratio, and fasting insulin level and $2 \mathrm{~h}$ glucose concentration. In both ethnic groups, adiponectin level positively correlated with insulinstimulated glucose disposal measured by a hyperinsulinemic-euglycemic clamp. Multivariate analysis demonstrated that hypoadiponectinemia was more closely related to the degree of insulin resistance and hyperinsulinemia than to the degree of adiposity or glucose intolerance. These results suggest that insulin resistance and hyperinsulinemia might be the major factor responsible for the hypoadiponectinemia in obesity and type 2 diabetes.

Recent genome-wide scans have mapped the diabetes susceptibility locus to chromosome $3 \mathrm{q} 27$, where the adiponectin gene (apM1) is located [21-23]. Evidence of the association between type 2 diabetes and single nucleotide polymorphisms: at positions 45, 276 $[24,25]$ in the proximal promoter and exon 3 [26] of the adiponectin gene has been reported. Some missense mutations in the globular domain have been also associated with low adiponectin level and type 2 diabetes [27]. However, the regulation of adiponectin gene expression is currently unknown.

The relationship between adiponectin and serum lipid concentration has recently been studied. In a large group of non-diabetic women with dyslipidemia, Matsubara et al [28] have shown that plasma adiponectin negatively correlated with serum triglyceride, atherogenic index, apo B or apo E, and positively with serum HDL-cholesterol or apo A-I levels. These data suggest that low adiponectin concentration is associated with some of the well-known risk factors for atherosclerosis, such as low HDL-cholesterol level of hypertriglyceridemia. A relationship between hypoadiponectinemia and the metabolic syndrome seems to be similar [29].

Experimental evidence suggests that adiponectin might play a protective role against atherosclerosis. Low plasma adiponectin has been reported in coronary heart disease. It is also associated with some risk factors of cardiovascular disease, such as male sex, high blood pressure, obesity, and type 2 diabetes mellitus $[26,29,30]$. During the early phase of atherosclerosis, the macrophage secretes various cytokines and growth factors that promote smooth muscle cell proliferation. Adiponectin has been shown to reduce the macrophages secretion of TNF- $\alpha$ and also to attenuate the biological effects induced by TNF- $\alpha$. In fact, 
this protein suppresses the secretion of TNF- $\alpha$ from macrophages and the formation of foam cell [31]. Adiponectin also inhibits the expression of intracellular adhesion molecule-1, endothelial cell adhesion molecule-1, and E-selectin in endothelial cells in vitro and prevents the attachment of monocytes to TNF- $\alpha$ prestimulated human aortic endothelial cells [19, 31, 32]. The above mentioned data suggest that this adipocyte-derived cytokine may exert anti-inflammatory and anti-atherogenic effects, especially in endothelial cells and macrophages, and, therefore, may play a protective role in experimental models of vascular injury and in the early events of the atherosclerotic process.

\section{STUdies In ChILDREN AND Adolescents}

The relationship between plasma adiponectin level and various anthropometric and metabolic factors has been extensively studied in adults. There are a limited number of such studies in children and adolescents. Potentially, hypoadiponectinemia, and also other risk factors, may cause early progression of atherosclerosis in childhood and modulate the risk of cardiovascular disease later on in adulthood.

Huang et al [33] have demonstrated a relationship between the level of plasma adiponectin and anthropometric parameters as well as cardiovascular risk factors in a group of non-diabetic adolescents (aged 1019). They show that the level of plasma adiponectin is significantly higher in girls than in boys and it is negatively related to BMI, body fat mass, percentage body fat mass obtained from DXA scan, waist circumference, waist-to-hip ratio, insulin resistance, plasma insulin, triglycerides, and the level of uric acid, but positively with high-density lipoprotein cholesterol (HDLC) when adjusted for age and gender. Using a different multivariate linear regression model, the authors show that only age and HDL-C is consistently related to the level of plasma adiponectin after adjustment for the other variables. These results suggest that plasma adiponectin level in childhood can serve as an independent risk factor for the development of the metabolic syndrome or cardiovascular disease later on in adulthood. However this hypothesis has to be confirmed by further investigations. In another study performed on Greek children and adolescents, Panagopoulou et al [34] have demonstrated that adiponectin is significantly lower in obese children and adolescents in comparison with age-matched nonobese children. The authors have found significant correlations between adiponectin and age, BMI, BMI standard deviation score, homeostasis model assessment for insulin resistance, and fasting glucose-to-insulin ratio. Adiponectin concentration correlated with the percentage of body fat after adjustment for sex. It also correlated significantly with several indices of insulin resistance, such as areas under the curves for glucose and insulin, whole-body insulin sensitivity index, glucose 120', and insulin 30' in obese patients.

These data are comparable to those described for subjects of other ethnic groups, such as African Americans [35], Mexicans [36], Pima Indians [37], Japanese [38] and Taiwanese [39]. Tsou et al [39] have demonstrated a transient drop in the level of adiponectin during puberty that correlates with increased testosterone in boys (10-12 years). The same study shows an inverse correlation of adiponectin with obesity and insulin resistance in both sexes during puberty. Woo et al [40] have reported sex differences of adiponectin level in adolescents and these differences were dependent on both pubertal stage and adiposity.

The association of adiponectin level with insulin sensitivity also has been analyzed in the above mentioned studies. Cruz et al [36] have described a strong association with HOMA-IR in Mexican children and conclude that a low level of adiponectin may predict type 2 diabetes in that ethnic group. Winer et al [41] have reported that adiponectin may function as a biomarker of the metabolic syndrome in childhood obesity because of its strong correlation with several indices of insulin resistance.

The mechanism of regulation of plasma adiponectin level and its negative association with body weight and adiposity is not yet fully understood. Children born with intrauterine growth retardation are at increased risk of developing type 2 diabetes and cardiovascular disease later in life [42, 43]. To explain this association the concept of 'reprograming' was introduced [44]. Fetal adaptation to an adverse intrauterine environment determines an altered programing of endocrine pathways, leading to permanent metabolic changes, including insulin resistance. Recent studies have shown that adiponectin has substantial effects on glucose homeostasis, by inhibiting hepatic glucose output, and on improvement in insulin sensitivity $[6,7]$. During fetal growth, glucose is the main energy source of the fetus and is supplied continuously from the maternal circulation [45]. Insulin increases the uptake of circulating glucose by fetal muscle and adipose tissue. There is little information about the role of adiponectin in fetal growth. A high concentration of adiponectin in the fetus may be crucial to enhance the growth-promoting effect of insulin through its insulin-sensitizing action. The relationship between plasma adiponectin level and birth weight seems as yet unclear. Tsai et al [46] have demonstrated that cord plasma concentration of adiponectin and leptin positively correlate with birth weight and adiposity, but not with insulin level in the fetal blood. These findings suggested that adiponectin may be involved in regulating fetal growth. The study on correlations between the fetal growth and adiponectin level of Kamoda et al [47] has shown in small-for-gestational-age (SGA) and appropriate-for-gestational-age (AGA) term neonates that the levels of serum adiponectin are significantly higher in all newborn infants than those later present in older children. The authors also have found that there is a significant difference in adiponectin level between SGA and AGA infants. Serum adiponectin level correlates positively with birth weight and head circumference in all newborns. There is no relationship between serum adiponectin level and gestational age, birth length, blood glucose level, or blood sampling time after birth. Nor is there a gender difference in adiponectin level in the entire newborn group examined in that report [47]. These results suggest that hyperadiponectinemia and a positive relationship between 
the serum level of adiponectin and birth weight in newborns cannot be explained only by a low percentage of body fat. Decreased adiponectin level in SGA compared with AGA infants is unlikely to suggest insulin resistance in the former in early postnatal life, but may be a predisposing factor for the future development of insulin resistance or type 2 diabetes.

Iniguez et al [48] has reported large variations in weight gain and insulin sensitivity during the first year of life of SGA and AGA neonates. These authors have determined whether adiponectin level was related to postnatal growth and insulin sensitivity in a prospective cohort followed from birth to two years of age. They have found that in the first 2 years of life, fasting adiponectin level is high, but it decreases with age and also with a rapid weight gain in SGA infants. In contrast to leptin level, there is no relationship between adiponectin and insulin levels.

The findings outline above support the concept that children born with SGA have a predisposition to develop insulin resistance and atherosclerosis. The assessment of adiponectin concentration in childhood may be helpful in identifying the risk of developing metabolic disorders in SGA children. There is also a potential possibility of a future therapeutic use of adiponectin in high risk SGA children. Further, longitudinal studies are needed to establish whether the reduced adiponectin secretion is related to a higher risk of type 2 diabetes and cardiovascular disease in adulthood. It seems worthwhile to consider the introduction of a simple measurement of serum adiponectin as a screening tool for predicting metabolic disturbances in the future life.

Conflicts of interest: No conflicts of interests were declared by the authors in relation to this article.

\section{REFERENCES}

1. Trujilio ME, Scerer PE. Adiponectin-journey from an adipocyte secretory protein to biomarker of the metabolic syndrome. J Intern Med 2005; 257: 167-75.

2. Diez JJ, Iglesias P. The role of the novel adipocyte-derived hormone adiponectin in human disease. Europ J Endocrinol 2003; 148: 293-300.

3. Scherer PE, Williams S, Fogliano M, Baldini G, Lodish HF. A novel serum protein similar to C1q produced exclusively in adipocytes. J Biol Chem 1995; 270: 26746-9.

4. Pajvani UB, Du X, Combs TP, Berg AH, Rajala MW, Schulthess T, Engel J, Brownlee M, Scherer PE. Structure-function studies of the adipocyte-secreted hormone Acrp30/adiponectin: implications for metabolic regulation and bioactivity. J Biol Chem 2003; 278: 9073-85.

5. Fruebis J, Tsao TS, Javorschi S Ebbets-Reed D, Erickson MR, Yen FT, Bihain BE, Lodish HF. Proteolitic cleavage product of $30 \mathrm{kDa}$ adipocyte complement-related protein increases fatty acid oxidation in muscle and causes weight loss in mice. PNAS 2001; 98: 2005-10.

6. Berg AH, Combs TP, Du X, Brownlee M, Scherer PE. The adipocyte-secreted protein ACRP30 enhances hepatic insulin action. Nat Med 2001; 7: 947-53.

7. Yamauchi T, Kamon J, Minokoshi Y, Ito Y, Waki H, Uchida S, Yamashita S, Noda M, Kita S, Ueki K, Eto K, Akanuma Y, Froguel P, Foufelle F, Ferre P, Carling D, Kimura S, Nagai R, Kahn BB, Kadowaki T. Adiponectin stimulates glucose utilization and fatty-acid oxidation. Nat Med 2002; 8: 1288-95.
8. Wang Y, Xu A, Knight C, Xu LY, Cooper GJ. Hydroxylation and glycosylation of the four conserved lysine residues in the collagenous domain of adiponectin potential role in the modulation of its insulin-sensitizing activity. J Biol Chem 2002; 277: 19521-9.

9. Kubota N, Terauchi Y, Yamauchi T, Kubota T, Moroi M, Matsui J, Eto K, Yamashita T, Kamon J, Satoh H, Yano W, Froguel P, Nagai R, Kimura S, Kadowaki T, Noda T. Disruption of adiponectin causes insulin resistance and neointimal formation. J Biol Chem 2002; 277: 25863-6.

10. Maeda N, Shimomura I, Kishida K, Nishizawa H, Matsuda M, Nagaretani H, Furuyama N, Kondo H, Takahashi M, Arita Y, Komuro R, Ouchi N, Kihara S, Tochino Y, Okutomi K, Horie M, Takeda S, Aoyama T, Funahashi T, Matsuzawa Y. Diet-induced insulin resistance in mice lacking adiponectin/ACR30. Nat Med 2002; 8: 731-7.

11. Ma K, Cabrero A, Saha PK, Kojima H, Li L, Chang BH, Paul A, Chan L. Increased beta-oxidation but no insulin resistance or glucose intolerance in mice lacking adiponectin. J Biol Chem 2002; 277: 34658-61.

12. Yamauchi T, Kamon J, Waki H, Terauchi Y, Kubota N, Hara K, Mori Y, Ide T, Murakami K, Tsuboyama-Kasaoka N, Ezaki O, Akanuma Y, Gavrilova O, Vinson C, Reitman ML, Kagechika H, Shudo K, Yoda M, Nakano Y, Tobe K, Nagai R, Kimura S, Tomita M, Froguel P, Kadowaki $\mathrm{T}$. The fat-derived hormone adiponectin reverses insulin resistance associated with both lipoathrophy and obesity. Nat Med 2001; 7: 941-6.

13. Fasshauer M, Klein J, Neumann S, Eszlinger M, Paschke R. Adiponectin gene expression is inhibited by betaadrenergic stimulation via protein kinase $\mathrm{A}$ in 3T3-L1 adipocytes. FEBS Lett 2001; 507: 142-6.

14. Delporte ML, Funahashi T, Takahashi M, Matsuzawa Y, Brichard SM. Pre- and post-translational negative effect of beta-adrenoreceptor agonists on adiponectin secretion: in vitro and in vivo studies. Biochem J 2002; 376: 677-85.

15. Hu E, Liang P, Spiegelman BM. AdipoQ is a novel adipose specific gene dysregulated in obesity. J Biol Chem 1996; 271: 10697-703.

16. Arita Y, Kihara S, Ouchi N, Takahashi M, Maeda K, Miyagawa J, Hotta K, Shimomura I, Nakamura T, Miyaoka K, Kuriyama H, Nishida M, Yamashita S, Okubo K, Matsubara K, Muraguchi M, Ohmoto Y, Funahashi T, Matsuzawa Y. Paradoxical decrease of an adipose-specific protein, adiponectin, in obesity. Biochem Biophys Res Commun 1999; 257: 79-83.

17. Yamamoto Y, Hirose H, Saito I, Tomita M, Taniyama M, Matsubara K, Okazaki Y, Ishii T, Nishikai K, Saruta T. Correlation of the adipocyte-derived protein adiponectin with insulin resistance index and serum high-density lipoprotein-cholesterol, independent of body mass index, in the Japanese population. Clin Sci (Lond) 2002; 103: 137-42.

18. Hotta K, Funahashi T, Arita Y, Takahashi M, Matsuda M, Okamoto Y, Iwahashi H, Kuriyama H, Ouchi N, Maeda K, Nishida M, Kihara S, Sakai N, Nakajima T, Hasegawa K, Muraguchi M, Ohmoto Y, Nakamura T, Yamashita S, Hanafusa T, Matsuzawa Y. Plasma concentrations of a novel adipose-specific protein, adiponectin in type 2 diabetic patients. Arter Throm Vasc Biol 2000; 20: 1595-9.

19. Ouchi N, Kihara S, Arita Y, Okamoto Y, Maeda K, Kuriyama H, Hotta K, Nishida M, Takahashi M, Muraguchi M, Ohmoto Y, Nakamura T, Yamashita S, Funahashi T, Matsuzawa Y. Adiponectin, adipocyte-derived plasma protein, inhibits endothelial NF-кB signaling through cAMP-dependent pathway. Circulation 2000; 102: 1296-1301.

20. Weyer C, Funahashi T, Tanaka S, Hotta K, Matsuzawa Y, Pratley RE, Tataranni PA. Hypoadiponectinemia in obesity and type 2 diabetes: Close association with insulin resistance and hyperinsulinemia. J Clin Endocrinol Metab 2001; 86: 1930-5. 
21. Takahashi M, Arita Y, Yamagata K Matsukawa Y, Okutomi K, Horie M, Shimomura I, Hotta K, Kuriyama H, Kihara S, Nakamura T, Yamashita S, Funahashi T, Matsuzawa Y. Genomic structure and mutations in adipose specific gene, adiponectin. Inter J Obes 2000; 24: 861-8.

22. Kissebah AH, Sonnenberg GE, Myklebust J, Goldstein M, Broman K, James RG, Marks JA, Krakower GR, Jacob HJ, Weber J, Martin L, Blangero J, Comuzzie AG. Quantitative trait loci on chromosomes 3 and 17 influence phenotypes of the metabolic syndrome. PNAS 2000; 97: 14478-83.

23. Stumvoll M, Tschritter O, Fritsche A, Staiger H, Renn W, Weisser M, Machicao F, Häring H. Association of the T$G$ polymorphism in adiponectin (exon 2) with obesity and insulin sensitivity: interaction with family history of type 2 diabetes. Diabetes 2002; 51: 37-41.

24. Hara K, Boutin P, Mori Y, Tobe K, Dina C, Yasuda K, Yamauchi T, Otabe S, Okada T, Eto K, Kadowaki H, Hagura R, Akanuma Y, Yazaki Y, Nagai R, Taniyama M, Matsubara K, Yoda M, Nakano Y, Tomita M, Kimura S, Ito C, Froguel P, Kadowaki T. Genetic variation in the gene encoding adiponectin is associated with an increased risk of type 2 diabetes in the Japanese population. Diabetes 2002; 51: 536-40.

25. Menzaghi C, Ercolino T, Di Paola R, Berg AH, Warram JH, Scherer PE, Trischitta V, Doria A. A halotype at the adiponectin locus is associated with obesity and other features of the insulin resistance syndrome. Diabetes 2002; 51: 2306-12.

26. Vasseur F, Helbecque N, Dina C, Lobbens S, Delannoy V, Gaget S, Boutin P, Vaxillaire M, Lepretre F, Dupont S, Hara K, Clément K, Bihain B, Kadowaki T, Froguel P. Single-nucleotide polymorphism halotypes in the both proximal promoter and exon 3 of the APM1 gene modulate adipocyte-secreted adiponectin hormone levels and contribute to the genetic risk for type 2 diabetes in French Caucasians. Hum Mol Gen 2002; 11: 2607-14.

27. Kondo H, Shimomura I, Matsukawa Y, Kumada M, Takahashi M, Matsuda M, Ouchi N, Kihara S, Kawamoto T, Sumitsuji S, Funahashi T, Matsuzawa Y. Association of adiponectin mutation with type 2 diabetes. A candidate gene for the insulin resistance syndrome. Diabetes 2002; 51: $2325-8$.

28. Matsubara M, Maruoka S, Katayose S. Decreased plasma adiponectin concentrations in women with dyslipidemia. J Clin Endo Metab 2002; 87: 2764-9.

29. Matsuzawa Y, Funahashi T Nakamura T. Molecular mechanism of metabolic syndrome $\mathrm{X}$ : contribution of adipocytokines adipocyte-derived bioactive substances. An NY Acad Sci 1999; 892: 146-54.

30. Kazumi T, Kawaguchi A, Sakai K, Hirano T, Yoshino G. Young men with high-normal blood pressure have lower serum adiponectin smaller LDL size, and higher elevated heart rate than that with optimal blood pressure. Diabetes Care 2002; 25: 971-6.

31. Ouchi N, Kihara S, Arita Y, Nishida M, Matsuyama A, Okamoto Y, Ishigami M, Kuriyama H, Kishida K, Nishizawa H, Hotta K, Muraguchi M, Ohmoto Y, Yamashita S, Funahashi T, Matsuzawa Y. Adipocyte-derived plasma protein, adiponectin suppresses lipid accumulation and class A scavenger receptor expression in human monocyte-derived macrophages. Circulation 2001; 103: 1057-63.

32. Ouchi N, Kihara S, Arita Y, Maeda K, Kuriyama H, Okamoto Y, Hotta K, Nishida M, Takahashi M, Nakamura T, Yamashita S, Funahashi T, Matsuzawa Y. Novel modulator for endothelial adhesion molecules: adipocytederived plasma protein adiponectin. Circulation 1999; 100: 2473-6.

33. Huang KC, Lue BH, Yen RF, Shen CG, Ho SR, Tai TY, Yang WS. Plasma adiponectin levels and metabolic factors in nondiabetic adolescents. Obes Res 2004; 12: 119-23.
34. Panagopoulou P, Galli-Tsinopoulou A, Fleva A, PavlitouTsiontsi E, Vavatsi-Christaki N, Nousia-Arvanitakis S. Adiponectin and insulin resistance in childhood obesity. J Pediatr Gastroenterol Nutr 2008; 47: 356-62.

35. Bush NC, Darnell BE, Oster RA, Goran MI, Gower BA. Adiponectin is lower among African Americans and is independently related to insulin sensitivity in children and adolescents. Diabetes 2005; 54: 2772-8.

36. Cruz M, Garcia-Macedo R, Garcia-Valerio Y, Gutiérrez M, Medina-Navarro R, Duran G, Wacher N, Kumate J. Low adiponectin levels predict type 2 diabetes in Mexican children. Diabetes Care 2004; 27: 1451-3.

37. Kadowaki T, Yamauchi T, Kubota T, Hara K, Ueki K, Tobe K. Adiponectin and adiponectin receptors in insulin resistance, diabetes, and the metabolic syndrome. J Clin Invest 2006; 116: 1784-92.

38. Ogawa Y, Kikuchi T, Nagasaki K, Hiura M, Tanaka Y, Uchiyama M. Usefulness of serum adiponectin level as a diagnostic marker of metabolic syndrome in obese Japanese children. Hypertens Res 2005; 28: 51-7.

39. Tsou PL, Jiang YD, Chang CC, Wei JN, Sung FC, Lin CC, Chiang CC, Tai TY, Chuang LM. Sex-related differences between adiponectin and insulin resistance in schoolchildren. Diabetes Care 2004; 27: 308-13.

40. Woo JG, Dolan LM, Daniels SR, Goodman E, Martin LJ. Adolescent sex differences in adiponectin are conditional on pubertal development and adiposity. Obes Res 2003; 11: 1072-9.

41. Winer JC, Zern TL, Taksali SE, Dziura J, Cali AM, Wollschlager M, Seyal AA, Weiss R, Burgert TS, Caprio S. Adiponectin in childhood and adolescent obesity and its association with inflammatory markers and components of the metabolic syndrome. J Clin Endocrinol Metab 2006; 91: 4415-23.

42. Barker DJ, Winter PD, Osmond C, Margetts B, Simmonds SJ. Weight in infancy and death from ischemic heart disease. Lancet 1989; 2: 577-80.

43. Barker DJ, Hales CN, Fall CH, Osmond C, Phipps K, Clark PM. Type 2 (non-insulin-dependent) diabetes mellitus, hypertension and hyperlipidaemia (syndrome X): relation to reduced fetal growth. Diabetologia 1993; 36: 62-7.

44. Fall CH, Pandit AN, Law CM, Yajnik CS, Clark PM, Breier B, Osmond C, Shiell AW, Gluckman PD, Barker DJ. Size at birth and plasma insulin-like growth factor-1 concentrations. Arch Dis Child 1995; 73: 287-93.

45. Sparks JW, Ross JC, Cetin I. Intrauterine growth and nutrition. In: Fetal and neonatal physiology, Polin RA, Fox WW (eds.) $2^{\text {nd }}$ Edition. Philadelphia, WB Saunders, 1998, pp. 267-89.

46. Tsai PJ, Yu CH, Hsu SP, Lee YH, Chiou CH, Hsu YW, Ho SC, Chu CH. Cord plasma concentrations of adiponectin and leptin in healthy term neonates: positive correlation with birth weight and neonatal adiposity. Clin Endocrinol 2004; 61: 88-93.

47. Kamoda T, Saitoh H, Saito M, Sugiura M, Matsui A. Serum adiponectin concentrations in newborn infants in early postnatal life. Pediatr Res 2004; 56: 690-3.

48. Iniguez G, Soto N, Avila A, Salazar T, Ong K, Dunger $\mathrm{D}$, Mericq V. Adiponectin levels in the first two years of life in a prospective cohort: relations with weight gain, leptin levels and insulin sensitivity. J Clin Endocrinol Metab 2004; 89: 5500-3.

Address for correspondence:

Beata Pyrzak

Department of Pediatrics and Endocrinology

Medical University of Warsaw

24 Marszalkowska St.

00-576 Warsaw, Poland

Phone: +48 225227435

Fax: +48 226214155

E-mail: beata.pyrzak@wum.edu.pl 